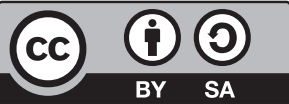

Xiaoyan Li

\title{
Learning Japanese Onomatopoeia through a Narrative-Evaluation E-Learning System
}

\begin{abstract}
In Japanese, onomatopoeia are important for expressing feelings and experiences. For students of Japanese, they are difficult to acquire, especially the nuances of meaning. We propose an e-learning system to enhance the efficiency of teaching the nuances of onomatopoeia in three steps - both explicit and tacit — to non-native speakers of Japanese. We synthesize a new learning strategy for students learning Japanese onomatopoeia, using narrative strategies to mimic the process by which native speakers learn. The first step is the teaching of the formal rules governing explicit nuances. In the second step, the learners create new onomatopoeia in accordance with those formal rules. In the final step, feedback is provided by evaluating the onomatopoeias created by the learners, using a narrative strategy support system to provide implicit teaching. To verify the effectiveness of the proposed method and learning system, we conducted an experiment involving two groups of subjects in the Japanese language department of a university in Shanghai, China. While Group A (23 students) got feedback about the appropriateness of their onomatopoeic constructions from the native speaker researchers' narrative interpretations, Group B (22 students) only reviewed the database material in a manner similar to that used in traditional classrooms. The e-learning system was found to have a significant effect on the acquisition by non-native learners of Japanese of a working understanding of, and skill in the use of, onomatopoeia.
\end{abstract}

Keywords: onomatopoeia, tacit nuance, narrative interpretation, e-learning system, second language teaching

According to JASSO (Japan Student Services Organization), 298,980 international students were studying in Japan as of May 1, 2018, and 64\% of them expressed a desire to work in Japan. Learning Japanese is a necessity for those international students. Moreover, the Japan Foundation reported that there were 3,846,773 formal learners of Japanese outside of Japan as of 2018. One challenging aspect of learning Japanese is that there are more than 5,000 
onomatopoeias in the Japanese dictionary, with people using even more in daily conversation. Onomatopoeia are used to describe sounds, mental states, movements, and feelings. They play an integral part in language; they are used frequently in everyday conversation to help bring events to life through vivid depiction and enactment (Perniss, Thompson, \& Vigliocco, 2010). When learned via traditional educational methods, onomatopoeia are typically memorized one by one, each in a specific context. However, most learners of Japanese can neither remember that huge array of onomatopoeia, and nor clearly comprehend the nuances of those onomatopoeia.

In this study, we examine the effectiveness of learning onomatopoeia nuance through a narrative evaluation approach. Based on the results of our verification experiment, we propose an e-learning system to help non-native learners of Japanese to understand Japanese onomatopoeia and be sufficiently familiar with them that they are able to use them.

\section{Literature Review}

Onomatopoeic constructions are heavily influenced by cultural and linguistic nuances; studies have shown that they are difficult to master for non-native Japanese language learners (Ivanona, 2006). There are several reasons for this difficulty. Firstly, while there are 5,000 to 7,000 onomatopoeia in most Japanese dictionaries, in daily conversation people use even more onomatopoeia than are officially listed. Secondly, inferring their meanings is difficult for the non-native. Onomatopoeia are verbal expressions of sounds and of people's sensibilities. A sensation can be described with various words, and may be hard to explain. For example, a patient might use words like zukizuki (ずきずき), gangan (ガンガン) and piripiri (ぴりぴり) to tell a doctor that she/he has a headache, and jinjin (じんじん) and gishigishi (ぎしぎし)" can be used to describe some kind of bodily ache. Thirdly, there are similar expressions with different nuances. For example, garagara (がらがら) can be used to express both a very parched throat and a train that has only a few passengers. Moreover, a lack of equivalent or similar expressions in the learner's first language is also an important reason for difficulty in acquiring onomatopoeias (Chen, Shirozu, \& Matsushita, 2013). In conclusion, onomatopoeia are complex and difficult to acquire: they are used to express feelings and sensations; a single onomatopoeia may have several meanings; and there may be no equivalent word in the learner's first language (Watanabe, 1997).

When dealing with onomatopoeia by means of traditional learning methods, some problems can appear in dictionaries or teaching material. In those methods, onomatopoeia are typically remembered one by one, each in a specific 
context. For example, it is very common to learn onomatopoeia by reciting an illustrative sentence provided in a dictionary or teaching material, and/or by repeatedly practicing selection problems. However, with such methods, the learning is limited to use in a specific context, so it remains difficult to develop full knowledge of an onomatopoeia completely (Mikami, 2003). Occasionally, target words may be quoted in excerpts from literary works, in which case comprehending an onomatopoeia requires comprehension of the work's cultural background. In that case, even with examples provided by an onomatopoeia dictionary, onomatopoeia can still be difficult for a second language learner to understand. On other occasions, when a specific word is not presented well in a sentence, the situations in which the word should be used will be obscure. Furthermore, comprehension is also difficult when abstract words are frequently used in explanations of meanings. In addition, some teachers of Japanese use manga as teaching material; they typically report that manga can heighten student motivation (Kumano, 2010). It is also claimed that using manga makes it easier to understand the situation in which the language occurs, because manga contains many pictures that provide contextual clues (Murakami et al., 2008). However, it is considered difficult to accurately convey the meaning and use of onomatopoeia with a single image. Even among native speakers of Japanese, onomatopoeia use varies subtly due to individual difference. Although Japanese contains a wide range of well-established onomatopoeias, native Japanese speakers often create their own neologisms. Moreover, it is considered that spontaneously created onomatopoeias are better accepted emotionally among friends (Sharlin, 2009; Uno, Kaji, \& Kitsuregawa, 2010). For the above three reasons, the teaching of nuances of Japanese onomatopoeia is not a well-developed practice.

We define situational nuance as a tacit nuance, where the deep meaning of a word is too obscure to be expressed in words. In order for students to understand and be able to utilize onomatopoeia, they should not only learn onomatopoeia by the traditional method mentioned above, but also study subtle tacit nuances. In this study, we set out to answer the following research questions, as a foundation for the creation of an e-learning system for Japanese onomatopoeia learning:

- What is an effective method for learning both explicit and tacit nuances of Japanese onomatopoeia?

- How do learners modify their compresence of onomatopoeia after receiving narrative native speaker feedback?

\section{Purpose and Methodology}

In this study, we explore new methods for learning onomatopoeia in the second language context. We think it is more important to understand the com- 
plexity of onomatopoeia use in real life than to be able to generate the correct answers to questions, especially for the understanding of nuance. Therefore, here we create a situation in which the learners are required to create their own onomatopoeias rather than choosing from among existing ones, since onomatopoeia also constitute a creative aspect of linguistic expression for native Japanese speakers (Sharlin, 2009; Uno, Kaji, \& Kitsuregawa, 2010). Since second language learners of Japanese do not possess the same level of nuance knowledge as native speakers, having L2 learners create their own onomatopoeias by following word-formation rules should be an effective approach to mastering the relationship between word/phoneme and explicit nuance.

For L2 learners of Japanese to learn to create their own onomatopoeia, they need the prerequisite knowledge of Japanese basic word-formation rules and structure. The word-formation rules characterize the explicit nuances of onomatopoeic words. Tamori (2010) proposes some nuance rules for creation of onomatopoeia with a certain inflection and phonology. For instance, one rule is that structures of two syllables repeated twice (i.e., ABAB, e.g., baribari, sarasara) express the nuance that the action lasts continuously up to the present. Such rules express an explicit nuance in Japanese onomatopoeia (Table 1).

Table 1.

Word-formation rules based on Tamori, 2010

\begin{tabular}{|c|c|}
\hline \multicolumn{2}{|c|}{ Rule-based word creation } \\
\hline $\begin{array}{l}\text { 繰り返し型 } \\
\text { Sound repetition } \\
\text { ABAB type }\end{array}$ & $\begin{array}{l}\text { 関わっている動作が今まさに続いているというニユアンスを表す。繰り返しの連続した継続 } \\
\text { の動作でられる。Reptition means the action described persists } \\
\text { up to the present. } \\
\text { Example:落とした消しゴムがころころと彼女の足下に転がっていった。 }\end{array}$ \\
\hline $\begin{array}{l}\text { 促音 } \\
\text { Sokuon } \\
\text { (double consonant) } \\
\text { AB つ type }\end{array}$ & 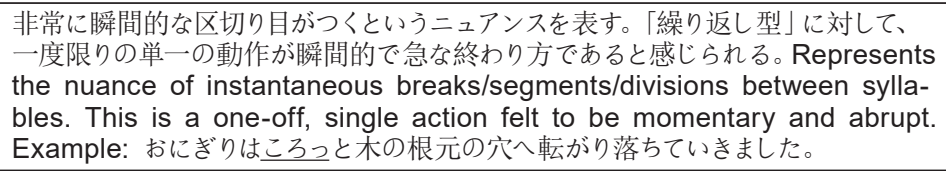 \\
\hline \multicolumn{2}{|l|}{ Phonological rules } \\
\hline \begin{tabular}{|l} 
濁音の効果 \\
The effect of \\
stronger sounds
\end{tabular} & 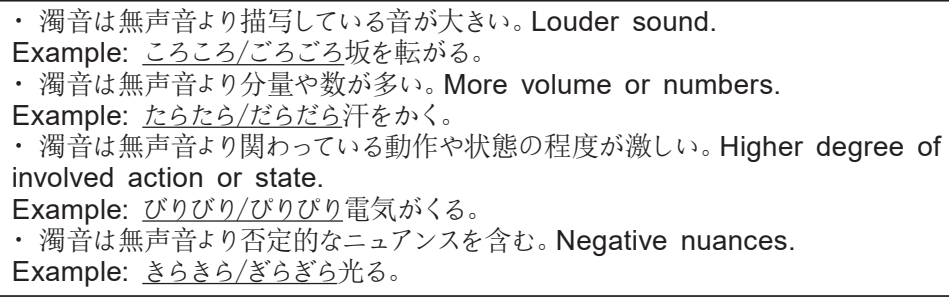 \\
\hline $\begin{array}{l}\text { さ行の滑らかさ } \\
\text { Smoothness of the } \\
\text { "sa shi su se so" } \\
\text { initial syllables }\end{array}$ & $\begin{array}{l}\text { ・[S]は日本語においても英語においても「滑らかさ」を表す。[S] represents } \\
\text { "smoothness” in both Japanese and English. } \\
\text { Example: 穂がさわさわ波立つ光景を思い浮かべる。 }\end{array}$ \\
\hline
\end{tabular}


Swain (1985) points out that in addition to comprehensible input, output practice is also effective, because when learners express their intended messages, they notice gaps between their expressions and the standard expression. This is an instance of the process in which a person builds a hypothesis based on his or her own knowledge, creates a language output, examines its validity vis a vis a model, and revises the hypothesis according to that feedback (Gass, Mackey, \& Pica, 1998; Muranoi, 2007). This output-feedback-revision loop is considered an effective method for acquiring knowledge without explicit explanation.

In this study, we create a structured e-learning system to support learners of Japanese in understanding and familiarizing themselves with Japanese onomatopoeia. In the method inherent in the system, the learners proceed through three phases:

1. learning the rules for forming onomatopoeias (forming explicit nuance);

2. creating onomatopoeias in accordance with those rules;

3. obtaining native speaker feedback about their generated onomatopoeias.

This empirical study consists of hypothesis formation, database structuring, and a verification experiment.

\section{E-learning System Based on a Narrative-Evaluation Approach}

\section{Creation of a Pilot System}

To begin, we created a structured e-learning system based on the three elements - rule learning, onomatopoeia creation, validate from feedback - mentioned in the last chapter. Regarding the provision of feedback, we decided to avoid using the five-point relative estimation scale used in our previous study (Yang et al., 2015). The students were confused by the five-point grading system in that study, because they could not understand the evaluation criteria based on numbers alone. Also, we wanted to gain insights into how they acquired the tacit nuances under the new system, even though the learning effect would be verified. In the design of this preliminary study, we replaced the five-point relative estimation scale with a narrative-based evaluation.

In the pilot study, we combined the above three steps to form a process (method) for the teaching of explicit and implicit nuance of Japanese onomatopoeia. As for rules for the formation of onomatopoeia, we adopted the typical rules for formation of Japanese onomatopoeias described in Tamori (2010). Then, we assigned the subjects two creation tasks involving application of the learned word-formation rules. The first task is to combine the morphemic rule 
of "repetition" and the phonemic rule of "the effect of voiced sound" (ABAB type). The second is to combine the rules of "use of sokuon" and "the smoothness of ' $s a$ ' and 'su'" (AB $\supset$ type). We constructed a feedback database from the narrative interpretations and also prepared a pre-test and post-test for verification of learning effectiveness.

When using onomatopoeia, even native speaker interpretation of the context will vary slightly from person to person. Therefore, in the creation of the narrative interpretation presented here, native speakers were asked to simulate their self-reflection on the implicit nuances that come into play unconsciously. They then transformed their self-reflection into words by intentionally utilizing metaphor or analogy, and finally write down the words that they will introduce to the readers. In order to reduce the cost of creating the database, we organized a few evaluators to evaluate, on a five-grade evaluation scale, all the onomatopoeic words that fit the double creation task. In our previous study (Yang et al., 2015), we set two experimental creation tasks for students learning onomatopoeia, the $\mathrm{ABAB}$ type and the $\mathrm{AB} \supset$ type ( $\supset$ pronounced as sokuon, meaning double consonant), to ascertain the most effective methodology for use in the main test. There are more than 5,000 Japanese onomatopoeia; more than $30 \%$ are $\mathrm{ABAB}$ type, and most of the others are of the $\mathrm{AB}$ `type. That is the basis for our choice of examples of these two major types. Since the onomatopoeias created by the learners may not exist, we call this process "creation" rather than generation. Based on the results, onomatopoeic words that scored two or higher became the target words for valuation in narrative interpretation, a two-step process.

Step 1: among the 1410 onomatopoeic words that were in accordance with the word formation rules in our two-create task, 174 had an average value of more than two on the five-point scale evaluation. We asked 15 Japanese native speakers to give narrative interpretations of those 174 words. Each native speaker interpreted 11 or 12 words.

Step 2: we shared the nuances from the interpretations on the website and asked all 15 native speakers to vote agree/disagree on each one. If they agreed with a narrative interpretation, they were to push the agree bottom. If they did not agree with a narrative interpretation, they were to contribute a new nuance.

The percentage of the vote for each onomatopoeia determined the order in which the onomatopoeia were shown to the learners of Japanese. Other nuances would be presented below the nuance assigned highest priority by the native speaker voting for best interpretation. Figure 1 is an example of the narrative interpretation feedback shown to learners using the system. 


\section{Preliminary Verification Experiment}

To verify the effectiveness and operability of the proposed method and the learning system, we conducted a preliminary experiment. The participants consisted of 36 international students at Kyushu University, Japan, 35 Chinese and one Korean, of average age 24.56 years $(\mathrm{SD}=2.20)$. All of them had passed level N1 of the Japanese Language Proficiency Test, meaning that they had the Japanese reading and writing ability required for participation in the experiment. The participants were divided into two groups.

The experimental procedure was as follows:

a) According to the design of the e-learning system, the participants were given 15 minutes to learn the word-formation rules provided as hard copy.

b) The creation tasks ${ }^{1}$ were assigned to the participants. This step was conducted in a computer environment. Each task required that 10 onomatopoeia be submitted following the requirements presented on the site. The participants were asked to create a total of 20 onomatopoeia. After a participant entered a newly created word in the blank space provided on the screen, the feedback from the database would be displayed. While Group A received feedback about the appropriateness of their onomatopoeic constructions in the form of native speaker narrative interpretation, Group B simply received numerical feedback on a five-point relative estimation scale. As shown in Figure 1, the percent

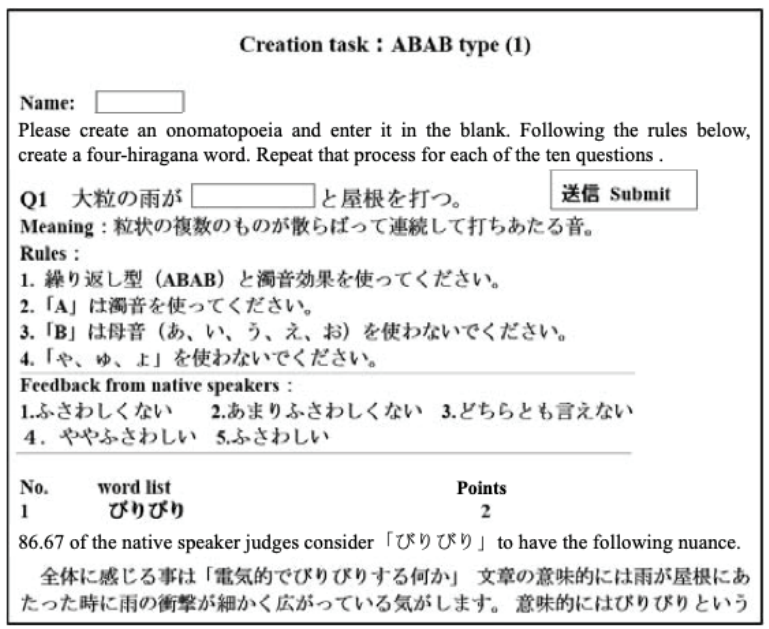

Figure 1. An example of narrative interpretation feedback

${ }^{1}$ In our preliminary verification experiment, we used task 1 (大粒の雨が_屋根に打つ) and task 2 (猫はドアの隙間を_と抜けて飛び出していった). Onomatopoeia frequently created by the students are shown in Appendix 1 (A). 
native speaker vote determined the order in which the onomatopoeia were shown to Group A. Other nuances of each onomatopoeia were presented to the participants below the nuance given the highest average native speaker evaluation in the voting for best interpretation. c) A questionnaire ${ }^{2}$ was administered concerning (a) participant motivation to learn onomatopoeia and (b) participant subjective impression of the study.

The questionnaire was administered to all participants to determine the accessibility of the learning system, and to identify aspects in need of improvement. The results of the questionnaire survey were analyzed to compare the learning effects of the two treatments. Figure 2 presents the knowledge attained by the two groups after using the e-learning system. As can be seen in Figure 2, our approach improved the effectiveness of learning of nuances and onomatopoeia for both groups: $94 \%$ of Group A and $89 \%$ of Group B members considered this system to be useful for learning nuances. Moreover, $100 \%$ of Group A members evaluated the learning method as appropriate or very appropriate for wider application in second Japanese language learning. We also solicited comments and advice about this narrative interpretation learning system by means of a free response questionnaire. The learners evaluated studying onomatopoeia by reading narrative feedback from native speakers as very efficient. Some learners reported improved self-confidence in the creation of new onomatopoeia, saying that although it took time to understand what native speakers were saying about the tacit nuances, there was a feeling of learning real Japanese.

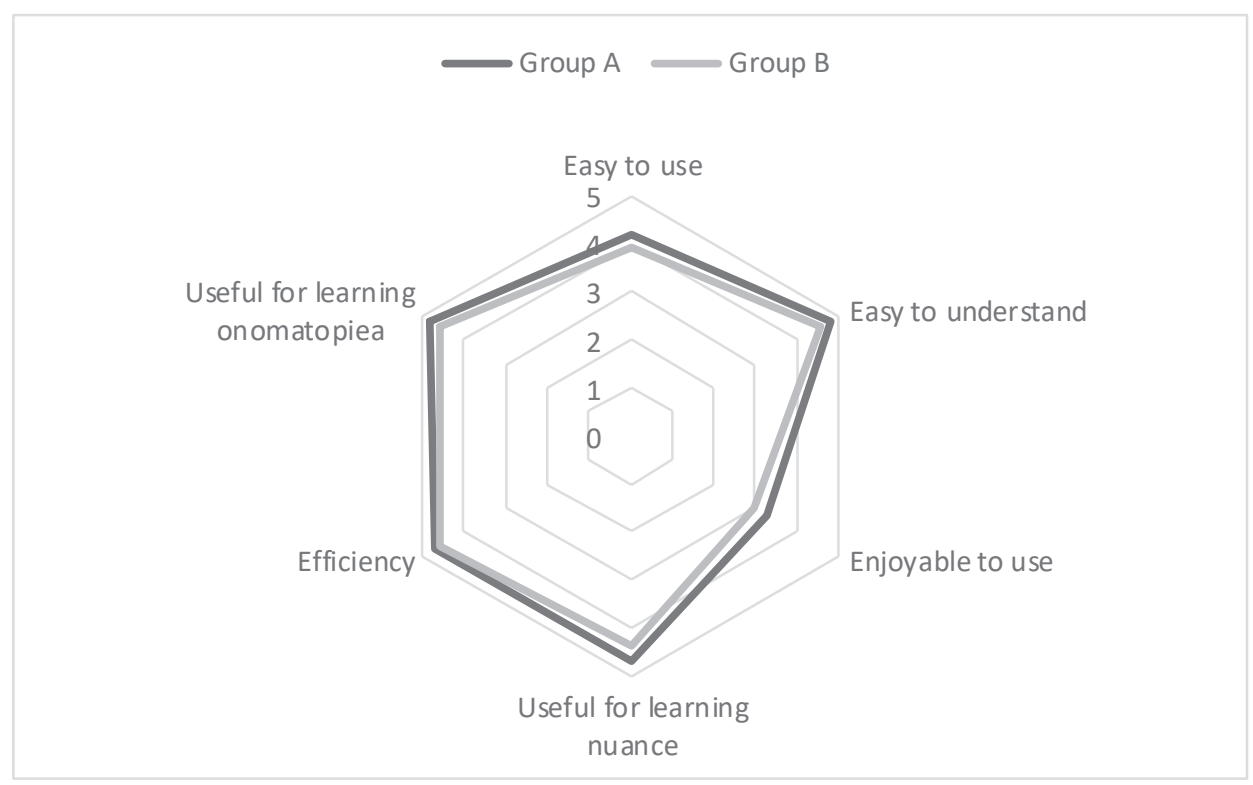

Figure 2. Questionnaire results

${ }^{2}$ Please refer to Appendix 1 (C). 
The evaluation of system was not uniformly unanimous: 33\% of Group A and $39 \%$ of Group B reported that it was difficult or a little difficult to use (Figure 2). We explored the reasons for that reaction through interviews with selected learners. Two main reasons were identified: (1) the content was not interesting, because all the sentences were related to the weather; and (2) the database gave feedback on new words in ascending order of evaluation, so learners who created new onomatopoeias using words further down the list had to make more effort to return to the top of the screen for the next iteration.

\section{Construction of the "Pa" Row Database and Improvement of the e-Learning System}

Based on the results of the preliminary verification experiment, we decided to use some familiar and easy to create onomatopoeia in the verification experiment. We found that a large number of onomatopoeia begin with characters from the "Pa" row. ${ }^{3}$ In Japanese, with the exception of some loan words, the "Pa" row contains only onomatopoeia (Hamano, 2014). About one-sixth (Asano, 1978) or one-seventh (Kakehi et al.) of all onomatopoeias begin with a character from the " $\mathrm{Pa}$ " row. For that reason, we constructed a " $\mathrm{Pa}$ " row database. We also improved this system by changing to a descending order for word lists, so that when a new word is created, it appears at the top of the word list.

The " $\mathrm{Pa}$ " row database allowed us to address some of issues identified earlier, and to create a wider range of topics, as seen in Figure 3, to avoid monotony (e.g., all sentences about weather).

Construction of the " $\mathrm{Pa}$ " row database. As mentioned above, onomatopoeia occur heavily in the "Pa" row, with the ABAB type the most common. We created a double-item task for the context of the onomatopoeia. One item was "the food is (この食べ物は している)" where onomatopoeia which completed the phrase would describe the state or texture of the food. The other item was "this unknown living thing is (この未知の生き物は

している)" where the onomatopoeia which would complete the phrase would describe what the living thing looks like or what it would feel like (Figure 3).

\footnotetext{
3 Japanese syllabaries are organized in the form of tables with vowel columns and consonant rows. The " $P a$ " row consists of the $\mathrm{P}$ consonant combined with the five vowels of Japanese to give the sounds $P a, P i, P u, P e$, and $P o$.
} 


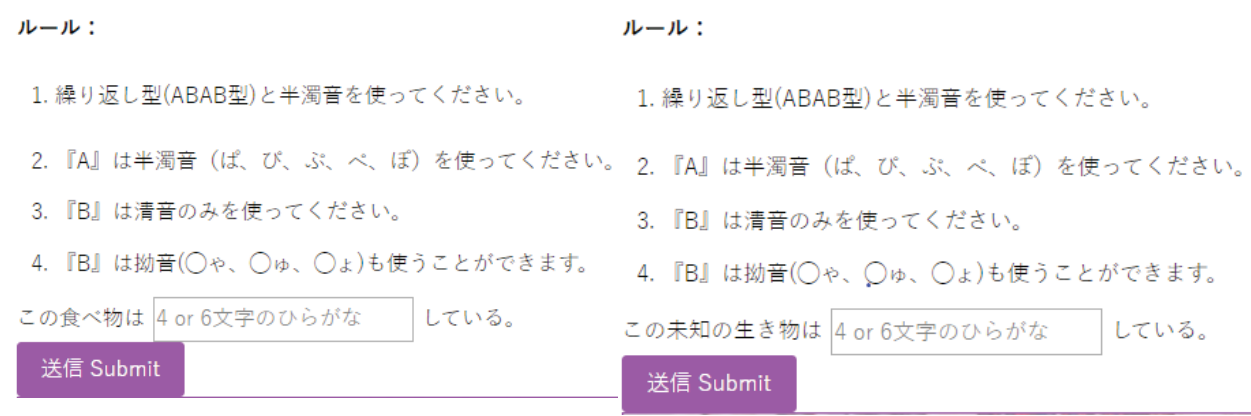

Figure 3. Creation tasks 3 and 4 (www.lixiaoyan.jp/1-2/)

We decided the following requirements for onomatopoeia creation.

(1) The "Pa" row database should be built using the ABAB type.

(2) A should be one of the sounds in the "Pa" column, that is to say, one of the 5 Kana $(p a, p i, p u, p e, p o)$.

(3) B should be one of the other sounds that follow Japanese phonetic rules (44 basic and 21 contracted syllables). We put all possible ABAB combinations meeting those requirements (a total of 325; $5 \times 44+5 \times 21$ ) into an Excel file. Then we asked three Japanese native speakers to evaluate (on a five-point rating scale) the probability that each letter string would be used as an onomatopoeia.

Based on the results, onomatopoeic words that scored two or higher were designated as target words to be evaluated in narrative interpretation, which involved the following two steps.

Step 1: Among the 325 " $\mathrm{Pa}$ " row words that obeyed the rules of word formation in our two-create task, 99 onomatopoeic words had an average assigned value of more than 2 on the five point scale. We asked five Japanese native speakers to give narrative interpretations of these 99 words. Each native speaker interpreted 19 or 20 words.

Step 2: We shared the nuances from the interpretations on the website and asked the five native speakers to vote on them. If they agreed with the narrative interpretation, they were to push the agree button. If they did not agree with a narrative interpretation, they were asked to add a new nuance.

Remediation of the e-learning system. As mentioned in Creation of a Pilot System, we structured the e-learning system and set two creation tasks, one of $\mathrm{ABAB}$ type, the other $\mathrm{AB} \supset$ type. Based on learner feedback in our preliminary verification experiment, we added two tasks involving creation of onomatopoeia with initial kana from the " $\mathrm{Pa}$ " row.

${ }^{4}$ Please refer to Appendix 1 (D). 


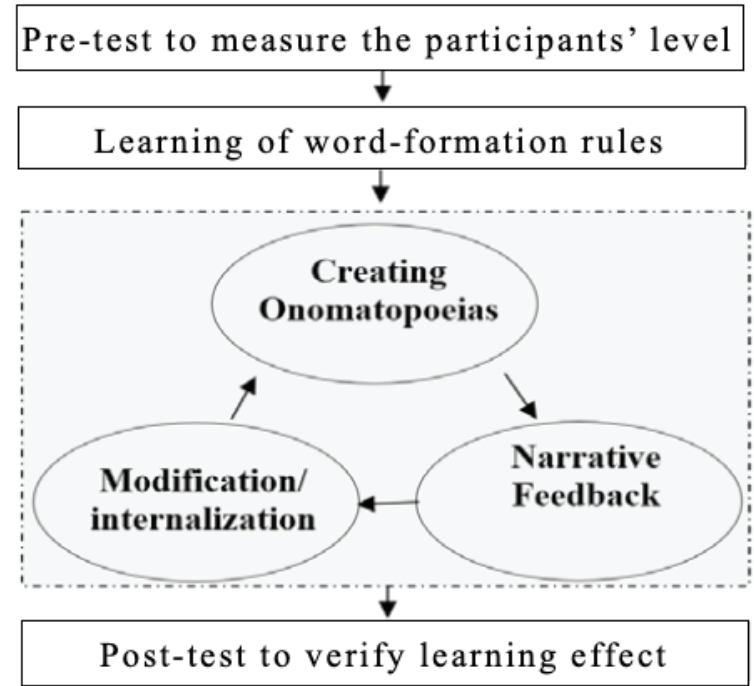

Figure 4. Flow of learning system

The flow of the learning system and the procedure for verification of the experiment are shown in Figure 4. A pre-test is given to the participants to measure the entry level of onomatopoeia competence. Then the participants are asked to learn the word-formation rules within a set time. The main objective is that the learners will learn the nuances of the onomatopoeias through the creation tasks. The learners receive narrative feedback from the database each time they create an onomatopoeia. They modify their methods when they recognize a gap between native speaker narrative and their own perception. Through that process they internalize the new awareness, including tacit nuances. A post-test is given after the learners have completed the e-learning system. Learning effect is defined as the difference between the pre-learning and post-learning test scores. A statistical analysis of the preand post-test results is conducted to compare the learning effect for the two groups.

\section{Verification Experiment}

Verification procedure. In June 2017, to verify the effectiveness of the proposed method and the e-learning system, we conducted a verification experiment in June 2017. The participants were 75 Chinese students in their third year in the Japanese language department of a university in Shanghai, China, but the group was reduced to 45 to remove outliers in language ability. The remaining participants had N2 Japanese Language Proficiency Test 
certificates, so they had the reading and writing ability required to perform this experiment. The participants were divided into two groups, Group A consisting of 23 students, Group B of 22 students. Before the experiment, the participants were told that the aim of the experiment was to develop an onomatopoeia learning system for second language learners of Japanese, and that in light of that objective, they were expected to take the experimental tasks seriously.

In the pre-test, the average score for Group A was 15.04 (out of 30); for Group B 15.36. T-test results showed no significant difference in onomatopoeia comprehension between the two treatments $(\mathrm{t}=0.858<\mathrm{t} 0.05=1.68,44)$. After the pre-test, all participants were given a 30-minute traditional lecture $^{5}$ on the word-formation rules, ${ }^{6}$ accompanied by examples of onomatopoeia from the "Pa" row. Group A and Group B were then seated in different rooms.

Group A participants were presented with a cloze task and were instructed to create an onomatopoeia and enter it in the blank space (Figure 3). The rules for creating the onomatopoeia were those presented in the mini-lecture, and the character length of the word to be created was pre-determined. If the word entered was in accordance with the word formation rules, native speaker evaluation of the word was given as feedback on a five-point evaluation scale from 1 "not suitable" to 5 "appropriate." For words receiving an evaluation greater than 1, feedback was also provided regarding the appropriateness of the onomatopoeic construction, in the form of native speaker narrative interpretation.

On the other hand, Group B received only learning material for study, similar to the process in traditional classes. The learning material was a database of words that had received an evaluation of 4 or more, that is, most correctly formed onomatopoeia. Finally, all the participants were asked to complete a post-test.

Experimental results. The average post-test score for Group A was 18.17 (out of 30), for Group B 16 (Figure 5). The learning effects of the two groups were determined by comparing the pre-test and post-test results. T-test showed a significant correlation between learning method (creation, learning) and test time (pre, post) $(\mathrm{t}=1.58<\mathrm{t} 0.05=2.015,44)$, that is, there was a significant improvement in performance between the pre-test and post-test in Group A, and Group A post-test performance was significantly higher than that of Group B. In other words, only Group A had learning effect.

5 The lecture is referred to as a "mini lecture" because it took only 30 minutes, compared to the standard lecture length of 90 minutes in Japanese and Chinese universities.

${ }^{6}$ The word-formation rules were almost the same as those taught in the preliminary study, which are shown in Table 1. 


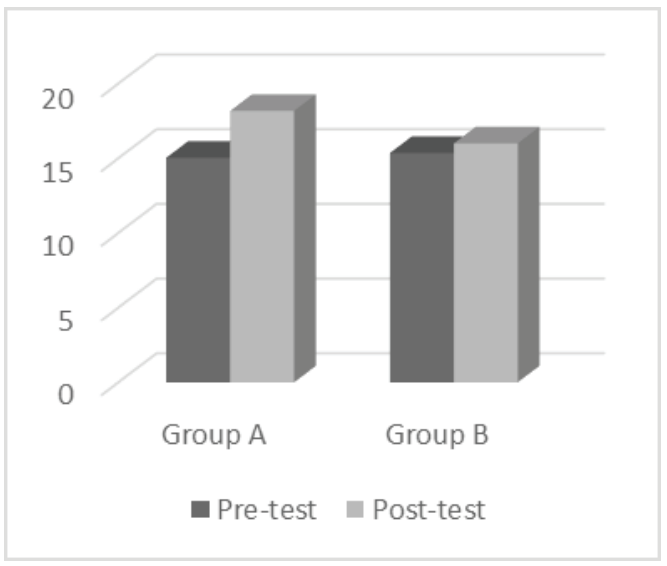

Figure 5. Result of Verification Experiment

\section{Discussion}

In this study, we addressed two research questions. What is an effective method for the learning of Japanese onomatopoeia, including both explicit and tacit nuances? How do learners modify their compresence of onomatopoeia from native speaker narrative feedback? In this chapter we set out to answer these questions. The e-learning system used here for teaching the tacit nuances of onomatopoeia, based on a narrative-evaluation approach, consists of three steps. First, the word-formation rules for representation of the explicit nuances of onomatopoeic words are taught. A knowledge of word-formation rules is non-intrusive and forms the basis for the development of autonomous and independent learners, especially for vocabulary production, creativity, understanding, and even proficiency (Balteiro, 2011). Second, the learners create new onomatopoeic words, applying those word-formation rules. Third, the subjects receive feedback in the form of native speaker evaluation of the onomatopoeias created. The results of the experiment demonstrate that an evaluation approach utilizing narrative interpretation is more effective than simple provision of feedback in the form of a five-point relative evaluation or mere review of study material in the manner used in traditional classrooms. The subjects learned explicit nuances by learning word-formation rules, and learned tacit nuances by creating onomatopoeias; modifying their linguistic hypotheses in light of narrative feedback; and constructing their own tacit nuances. The results show that the e-learning system presented here, based on a narrative-evaluation approach, is an effective method for the learning of Japanese onomatopoeia and their explicit and tacit nuances. 
The meanings of words can be likened to an iceberg. Dictionary meanings and explicit nuances are like the tip of the iceberg above the surface, while the tacit nuances which we use subconsciously are like the submerged, much larger part of the iceberg, as shown in Figure 6, based on Weaver (1986). The part 'above the surface' is relatively easy to grasp, but the part hidden 'underwater' is very difficult for learners to understand. This 'hidden' part of onomatopoeia is what is referred to as tacit knowledge.

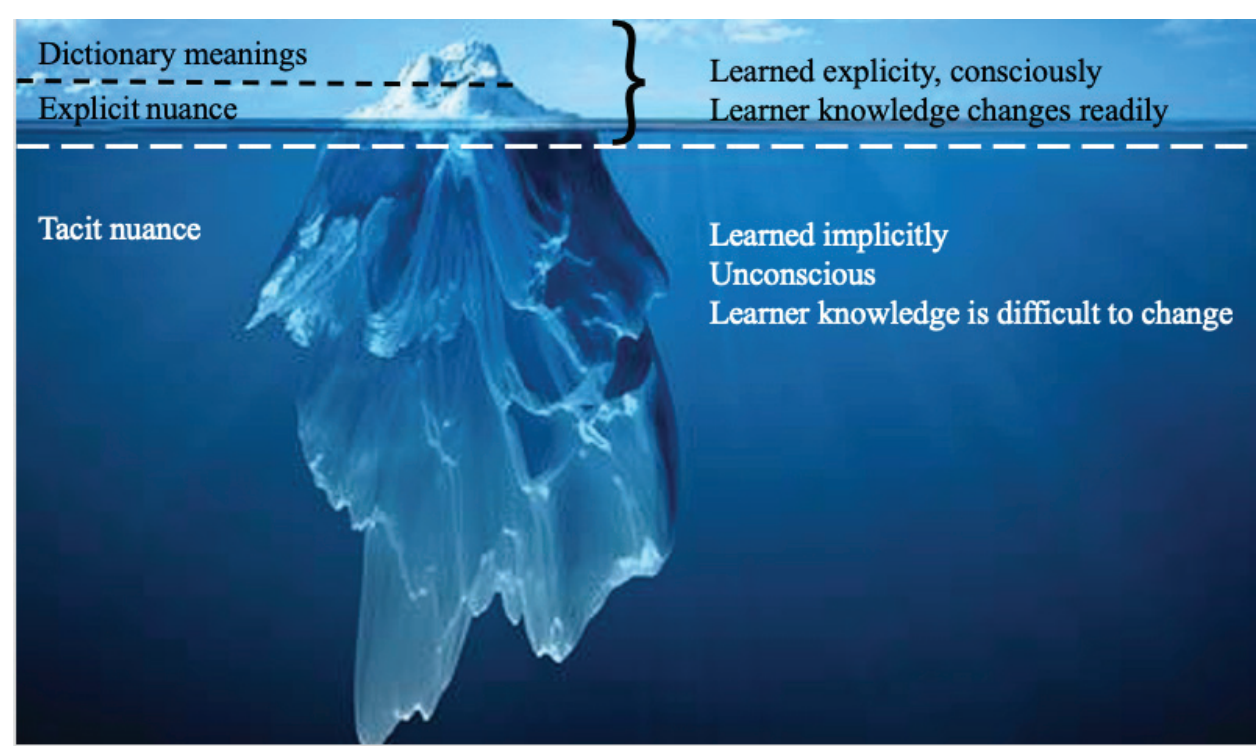

Figure 6. The 'Iceberg Analogy' of language meaning

Tacit knowledge has two components. One component can be converted to explicit knowledge using metaphor or analogy; the other part cannot be fully converted to explicit knowledge - it can only be learned from experience (Eraut, 1985). Even native speakers may perceive different nuances for one onomatopoeia, and their judgement of usage in a specific context may vary considerably. Moreover, depending on the occasion or situation, nuance may vary within a given context. Thus, it is difficult to account for such diversity or fluctuation. It is thought that people learn tacit nuance from their experience and use of language from infancy, not only by passively accumulating language experience, but also by expressing themselves, eventually acquiring full fluency in their mother tongue.

We improved the feedback database by including an evaluation based on narrative interpretation utilizing narrative interpretation, where learners can learn tacit nuances which then become explicit. As shown in Figure 7, students learn explicit nuances in the course of learning word-formation rules, 
creating onomatopoeias, getting narrative feedback to modify their linguistic hypotheses. In the process of that cyclic learning, learners gain an awareness of tacit nuances, which cannot be expressed linguistically, then internalize the new awareness and create output again to continue their learning experience. Through this approach, language learners can get feedback, repeat their hypothesis refinement and construct their own implicit nuances. In particular, for the learning of explicit nuances of onomatopoeia, we extract word-formation rules from existing onomatopoeias and have the learners memorize those rules. Then, to learn tacit nuances, the learners are asked to use the rules to create onomatopoeias suitable for given contexts. In this way, the learners become able to express their own nuances. This approach answers our second research question as to how learners can modify their compresence of onomatopoeia by means of native speaker narrative feedback.

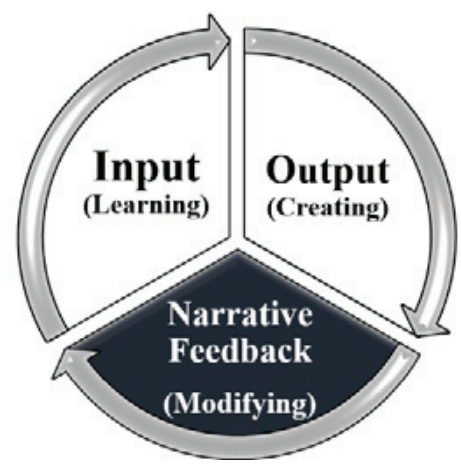

Figure 7. The stages of the E-learning system

Li \& Umemoto (2013) and Li (2017) characterize the interaction of tacit knowledge and explicit knowledge as a process of articulation, socialization, consolidation, and internalization, iterating in a spiral fashion. This harmonizes with the findings of this study, where the same language learning spiral is achieved through the sequence: learning the tacit nuances of Japanese onomatopoeia as articulated by native speakers; being socialized through an e-learning system; consolidating own knowledge with established sources of nuances; and arriving at a new internalized awareness of onomatopoeia. It is expected to be an effective method for use in a learning system to support understanding and then creation of onomatopoeia. 


\section{Conclusion}

We propose an e-learning system to support second language learners of Japanese in the learning of both explicit and tacit nuances of onomatopoeia through an evaluation approach utilizing narrative interpretation. The results demonstrate that the system is highly effective as a learning tool; the promising results of the preliminary test are supported by the results of the subsequent verification test used to ascertain the validity of the first set of results. The stages of this learning system are: repetitive learning of word-formation rules; creation of onomatopoeic words by applying those word-formation rules; and receiving feedback in the form of native speaker narrative interpretation. The three stages only constitute a complete method when used in combination. Word-formation rules and narrative feedback are the elements of tacit nuance that can be converted to explicit knowledge by means of metaphor or analogy. Tacit nuance cannot be completely converted to explicit knowledge: learners only learn from active experience, in this case the creation of onomatopoeias. This process (repetitive learning of word-formation rules; creation of new onomatopoeias; and attaining new awareness from narrative interpretations) is sufficient for the acquisition of explicit and tacit nuances of onomatopoeia. Here the interaction between native speakers and learners is not face to face, but they do interact in an asynchronous manner that allows the learner to effectively create new knowledge through the spiral process of articulation, socialization, consolidation, and internalization. Promising directions for future research include addition of new types of onomatopoeia to the e-learning system and enrichment of the narrative interpretation database. We plan to put this e-learning system to practical use so as to broaden the scope of language learning approaches available to learners.

\section{References}

Balteiro, I. (2011). Awareness of L1 and L2 word-formation mechanisms for the development of a more autonomous L2 learner. Porta Linguarum, 15, 25-34.

Chen, Y., Shirozu, N., \& Matsushita, M. (2013). A Survey of onomatopoeia in Japanese comics created for Chinese speakers. The 27th Annual Conference of the Japanese Society for Artificial Intelligence. (In Japanese).

Eraut, M. (1985). Knowledge creation and knowledge use in professional contexts. Studies in Higher Education, 10(2), 117-133.

Gass, S. M., Mackey, A., \& Pica, T. (1998). The role of input and interaction in second language acquisition-Introduction to the special issue. The Modern Language Journal, 82(3), 299-307. 
Ivanona, G. (2006). Sound-symbolic approach to Japanese mimetic words. Toronto working Papers in Linguistics, 26, 103-114.

Kumano, N. (2010). Japanese learners and animation/MANG: Present Situation and Needs Seen from Interview Results, Bulletin of Centre of International Students Hiroshima University, 20, 89-103. (In Japanese).

Li, X. \& Umemoto, K. (2013). Knowledge creation through inter-cultural communication in multi-cultural groupwork. Intercultural Communication Studies, 21(1), 229-242.

Li, X. (2017). Multicultural group work in creative learning on language and culture: Active learning from a knowledge science perspective. Tokyo: Koko Shuppan. (In Japanese).

Mikami, K. (2003). The current situation and the provision in Japanese onomatopoeia education. Proceedings of the 7th Symposium on Japanese Language Education in Europe, 254-261. (In Japanese).

Murakami, Y., Noyama, H., \& Kaneko, S. (2008). How to use manga for Japanese language education. Japanese, 21(5), 26-29. (In Japanese).

Muranoi, H. (2007). Output practice in the L2 classroom. In R. M. DeKeyser (Ed.), Practice in a second language: Perspectives from applied linguistics and cognitive psychology (pp. 51-84). Cambridge: Cambridge University Press.

Perniss, P., Thompson, R. L., \& Vigliocco, G. (2010). Iconicity as a general property of language: Evidence from spoken and signed languages. Frontiers in Psychology, 1(2-22), 1-15.

Sharlin, N. (2009). Sounds like: Understanding Japanese sound symbolism. Master's thesis, Bryn Mawr College.

Swain, M. (1985). Communicative competence: Some roles of comprehensible input and comprehensible output in its development. In S. M. Gass \& C. G. Madden (Eds.), Input in second language acquisition (pp. 235-253), Rowley: Newbury House Publishers.

Tamori, I. (2010). Enjoy the Japanese onomatopoeia! Tokyo: Iwanamishoten. (In Japanese).

Weaver, G. (1986). Understanding and coping with cross-cultural adjustment stress. In R. M. Paige (Ed.), Cross-cultural orientations: New conceptualizations and applications (pp. 111-145). Lanham: University Press of America.

Uno, Y., Kaji, N., \& Kitsuregawa, M. (2010). Exploring from/meaning interaction through the analysis of newly created verbs in Japanese. Proceedings of the Japanese cognitive linguistics association, 10, 377-386. (In Japanese).

Watanabe, Y. (1997). A Study on how onomatopoeia is handled in teaching Japanese as a second language. School Education Studies, 9, 23-31. (In Japanese).

Yang, S., Hashimoto, T., Li, G. \& Li, X. (2015). Learning system for Japanese onomatopoeia's nuance through creation task, transactions of the Japanese Society for Artificial Intelligence, 30-1, 331-339. (In Japanese).

Appendix 1

Top 5 most frequently created onomatopoeia for each creation task.

\begin{tabular}{|l|l|l|l|l|l|}
\hline Task 1: 大粒の雨が一屋根に打つ & ざわざわ & ばらばら & ぼかぼか & だらだら & ぼたぼた \\
\hline $\begin{array}{l}\text { Task 2: 猫はドアの隙間を } \\
\text { と抜けて飛び出していった }\end{array}$ & さらっ & さりっ & すらっ & さくっ & すすっ \\
\hline Task 3: この食べ物は している & ぴちぴち & ぽよぽよ & ぴくぴく & ぱらぱら & ぽきぽき \\
\hline $\begin{array}{l}\text { Task 4: この未知の生き物は } \\
\text { している }\end{array}$ & ぷるぷる & ぷよぷよ & ぺこぺこ & ぺちょぺちょ & ぽつぽつ \\
\hline
\end{tabular}


B. All onomatopoeia questions used in the tests are taken from past questions of the Japanese Language Proficiency Test (N1 \& N2) and modified by author for clarity.

B.1. Pre-test

Question 1: Please judge whether the following onomatopoeia usage is natural. If you think it is natural, put a $\vee$ inside the brackets. (Multiple selections possible)

(A)

1. だれでも二週間で英語がペらペらしやべれる方法が書いてあります。( )

2. 不合格と知り、彼は掲示板の前にペらペらと崩れ込んだ。( )

3. ペらペらしていたが、だいぶ頭にきていたんじやないかな。（ )

4. その店にあったペらぺらの小さい広州市内地図を買った。( )

5. まるで自分が作ったようにペらペら説明していたが、彼は自分では何もしていないんだよ。（ )

(B)

1. 休日は家でぷりぷり過ごすのがいちばんだ。( )

2. 新鮮でぷりぷりした貝は潮の香りがした。( )

3. あのウエイトレス、ぷりぷり怒って行ってしまって呼んでも来てくれない。( )

4. 折り箱をぷ於り壊し、束ねて捨てる。（）

5. 水から上がった犬は体をぷりぷりと振って水をはね飛ばす。（）

(C)

1.」よほどありがたかったとみえて、母は電話にペこペこ頭を下げて礼を言っていた。( )

2. お皿がみんなペこペこだ。熱湯に入れて洗剤で洗ってく。( )

3. 長年使って底がペこペこになったなべを今でも大事そうに使っている。（）

4. 太郎と花子がスリッパをペこペこと鳴らしながらやってきた。( )

5. 寝ぼうして朝飯を食べずに出てきたんで腹がペこペこだ。( )

Question 2: Please judge whether the following onomatopoeia usage is natural. If you think it is natural, put $\mathrm{a} \vee$ inside the brackets. (Please select one)

(A)

1. 高い空に雲がぱかぱかと浮いている。

2. 高い空に雲がぴかぴかと浮いている。

3. 高い空に雲がぷかぷかと浮いている。

4. 高い空に雲がペかペかと浮いている。

5. 高い空に雲がぽかぽかと浮いている。

(B)

1. すくいあげた網の中で小魚がぴかぴかはねていた。 すくいあげた網の中で小魚がぴきぴきはねていた。

2.

3. すくいあげた網の中で小魚がぴちぴちはねていた。

4. すくいあげた網の中で小魚がぴとぴとはねていた。

5. すくいあげた網の中で小魚がぴやぴやはねていた。

(C)

1. 袋に穴があいていて、持ちあげると小豆がぱたぱたこばれ出た。

2. 袋に穴があいていて、持ちあげると小豆がぱしやぱしやこぼれ出た。

3. 袋に穴があいていて、持ちあげると小豆がぴろぴろこぼれ出た。

4. 袋に穴があいていて、持ちあげると小豆がぴしやぴしやこぼれ出た。

5. 袋に穴があいていて、持ちあげると小豆がぽろぽろこぼれ出た。 


\section{B.2. Post-test}

Question 1: Please judge whether the following onomatopoeia usage is natural. If you think it is natural, put a $\vee$ inside the brackets. (Multiple selections possible)

(A)

1. 雨がぱらぱら落ちてきた。( )

2. 花見の宴会も始まったが、15日は平日のため見物客はぱらぱらだ

3. ～ボーイフレンドの運転の乱暴さにいつもぱらぱらさせられる。( )

4. 私は日記をぱらぱらとめくつてみました。( )

5. 1週間に1度部屋をぱらぱらと掃いて、掃除は終わりです。( )

(B)

1. 純子さんはぽりぽり涙を流していた。( )

2.・ピーナッツをぽりぽりかじりながらテレビを見る。( )

3. 空き地のままの区画には丈の高い雑草がぽりぽりと生えている。( )

4. なんだか照れくさくて、テレビの前で頭をぽりぽり掻いてしまいました。( )

5. まだ大学でのぽりぽりだから、よろしくご指導ください。( )

(C)

1. 鳥は朝になるとかでから出たくて、ぱたぱた羽をはばたかせて催促する。( )

2. 子供は目にごみがはいったらしく、涙ぐんで目をぱたぱたさせていた。( )

3. あの子は小学校のときからぱたぱたして利発な子だった。( )

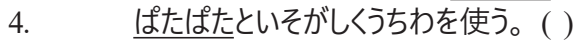

5. 鼻の頭をぱたぱたたたいてお化粧直しをしている。( )

Question 2: Please judge whether the following onomatopoeia usage is natural. If you think it is natural, put a $\sqrt{ }$ inside the brackets. (Please select one)

(A)

1. このパンはぱくぱくでおいしくない。

2. このパンはぱきぱきでおいしくない。

3. このパンはぱこぱこでおいしくない。

4. このパンはぱさぱさでおいしくない。

5. このパンはぱちぱちでおいしくない。

( )

( )

( )

( )

( )

(B)

1.

(これは) ぷよぷよのおなかを鍛える体操（です）。

( )

(これは) 孞つぷつのおなかを鍛える体操 (です)。

( )

(これは) 孞すぷすのおなかを鍛える体操 (です)。

( )

(これは) 孞らふららのおなかを鍛える体操 (です)。

( )

(これは) 予ちぷちのおなかを鍛える体操 (です)。

( )

(C)

1. ひと口食べたとたん舌がぴくぴくするほど辛くて、あわてて水を飲んだ。

2. ひと口食べたとたん舌がぴりぴりするほど辛くて、あわてて水を飲んだ。

3. ひと口食べたとたん舌がぷりぷりするほど辛くて、あわてて水を飲んだ。

4. ひと口食べたとたん舌がぷくぷくするほど辛くて、あわてて水を飲んだ。

5. ひと口食べたとたん舌がペこぺこするほど辛くて、あわてて水を飲んだ。 
C. 実験後アンケートPost-experiment questionnaire:

1. この学習システムの操作は、難しかったですか。Was it difficult to operate this learning system?

2. この学習システムについての説明は十分ですか。Is the description of this learning system sufficient?

3. この学習システムは楽しいと思いますか。Do you find this learning system enjoyable to use?

4. この学習システムは、擬音語・擬態語の学習に役に立つと思いますか。Do you think this learning system is useful for learning onomatopoeia?

5. 新しい擬音語·擬態語を学習する際に、またこの学習システムを利用したいと思いますか。Would you like to use this learning system again when learning new onomatopoeia?

6. 擬音語·擬態語の学習においてこの学習システムのどういうプロセスが役に立つと思いますか。(複数選 択可) What process in this learning system do you think is useful in learning onomatopoeia and mimetic words? (Multiple selections possible)

ルールの学習 Learning rules オノマペの創作プロセス Creation process for onomatopoeia

フィードバックをもらえる Receiving feedback その他 Other

7. この学習システムによって、オノマトペのニュアンスを学習できたと思いますか。Do you think you could learn the nuances of onomatopoeia with this learning system?

8. あなたが今までに使ったことがある学習方法と比べると、この学習システムはより効率が高いと思います

か。Do you think this learning system is more efficient than the learning methods you have used so far?

9. この実験を通じて、擬音語、擬態語に興味を持つようになりましたか。Did you become interested in onomatopoeia through this experiment?

10. この実験を通じて、これから擬音語·擬態語をもつと勉強しようと思いましたか。Do you want to study more onomatopoeia through this experiment?

11. この実験を通じて、日本語に興味を持つようになりましたか。Did you become interested in Japanese through this experiment?

12. この実験を通じて、これから日本語をもっと勉強しようと思いましたか。Do you want to study more Japanese through this experiment?

13. ほかの分野の学習においても、この学習システムを使いたいと思いますか。Do you want to use this learning system for learning in other fields?

14. この学習システムについてのご意見・ご感想を書いてください。(自由記述) Please write your opinion about this learning system. (Free description)

15.この学習システムを通じて、日本語また日本人の表現の仕方についての気づきを書いてください。（自由 記述) Please write down your awareness about Japanese and Japanese expression through this learning system. (Free description)

D. There are four creation tasks in our E-learning system in total.

Task 1: 大粒の雨が 屋根に打つ。Heavy rain hits the roof .

Task 2: 猫はドアの隙間をと抜けて飛び出していった。The cat jumped through the door gap

Task 3: この食べ物はしている. This food is .

Task 4: この未知の生き物は している. This unknown creature is . 
Xiaoyan Li

\title{
Das Lernen japanischer Onomatopoetika durch ein Narrative-Evaluation-basiertes E-Learning-System
}

\begin{abstract}
Zusammenfassung
Im Japanischen sind Onomatopoetika wichtig, um Gefühle und Erlebnisse auszudrücken. Für Studenten der japanischen Sprache sind sie schwer zu erlernen, insbesondere ihre Bedeutungsnuancen. Deswegen wird ein E-Learning-System vorgeschlagen, um den Nichtmuttersprachlern des Japanischen die Nuancen der Onomatopoesie in drei Schritten - sowohl explizit als auch implizit - effizienter zu vermitteln. Im Resultat wird eine neue, auf narrative Strategien gestützte und den Lernprozess von Muttersprachlern imitierende Lernmethode für Studenten entwickelt, die japanische Onomatopoetika lernen. Der erste Schritt ist das Lehren der formalen Regeln von expliziten Nuancen. Im zweiten Schritt kreieren die Studenten neue Onomatopoetika anhand der formalen Regeln. Im letzten Schritt erfolgt ein Feedback, indem die von den Studenten kreierten Onomatopoetika bewertet werden. Dabei wird ein Unterstützungssystem für narrative Strategie verwendet, um implizites Lehren $\mathrm{zu}$ ermöglichen. Um die Effektivität der vorgeschlagenen Methode und des Lernsystems $\mathrm{zu}$ verifizieren, wurde ein Experiment mit zwei Gruppen von Probanden an der Fakultät für japanische Sprache einer Universität in Shanghai in China durchgeführt. Während die Gruppe A (23 Studierende) ein Feedback über die Angemessenheit ihrer onomatopoetischen Konstruktionen von den muttersprachlichen Forschern erhielt, überprüfte die Gruppe B (22 Studierende) nur den Datenbankinhalt, ähnlich wie im traditionellen Unterricht. Es wurde festgestellt, dass das E-Learning-System einen signifikanten Effekt auf den Erwerb eines praktischen Verständnisses von Onomatopoetika und die Fähigkeit, sie zu verwenden, von Nichtmuttersprachlern des Japanischen hat.
\end{abstract}

Schlüsselwörter: Onomatopoesie, implizite Nuance, narrative Interpretation, E-LearningSystem, Zweitsprachenunterricht 
